\title{
The Augmented Reality Technologies in Tourism: A State of Art
}

\author{
Gheorghe Epuran \\ epuran.gheorghe@unitbv.ro \\ Ioana Bianca Chițu \\ Simona Ivasciuc \\ Transilvania University Of Brasov,Romania
}

\begin{abstract}
In tourism, as in other economic sectors, technological innovation plays a very important role in achieving the companies' objectives and, also, in meeting consumers' desires as much as possible. In this context, the concrete benefits of the augmented reality in the field of tourism have been identified in the paper, starting from the concrete examples of its application provided by the literature. At the same time, the main expectations of its potential users were determined, namely, on the one hand, the companies operating in the field of tourism and on the other side the tourists
\end{abstract}

Keywords: Marketing mix, 4 E's, hotel business

\section{Introduction}

The internet and digital technologies are transforming our world. The growth of Information and Communication Technology has delivered such a vast amount of information that the term 'information society' was created to refer to a society characterized, above all, by the global and massive scale in which raw data are created and disseminated (Ariso, J.M , 2017). As David and Foray (2002) pointed out, information 'takes the shape of structured and formatted data-sets that remain passive and inert until used by those with the knowledge needed to interpret and process them' (p.12). The term 'knowledge society' represents progress in relation to 'information society' just because information becomes valuable. According to UNESCO (2005), in knowledge societies everyone must be able 'to develop cognitive and critical thinking skills to distinguish between "useful" and "useless" information' (p.19). Information should be transformed into knowledge which can be applied in diverse contexts for improving our quality of life. Bearing this in mind, Augmented Reality (AR)can be regarded as a technological resource that may contribute to facilitate the transition from information society to knowledge society.

Augmented reality it's a term that gets the tech elite excited yet is often misunderstood and hard to define. While it's bubbled around in the world of business for decades, it's only in recent years has been starting to make the jump to the consumer world. The technology with which you could see more than others see, hear more than others hear, and perhaps even touch, smell and taste things that others cannot, deserve a proper attention in tourism industry to.

For many countries, tourism is one of the largest industries in their domestic economies. The new dynamics of the twenty-first century led to a new competitive environment in the field of tourism and hospitality business. The tourist business is always trying to keep pace with time and to step up the game with new technology. Especially now, when the dominant part of travellers are the millennials. Millennials changed and influenced the tourism industry. In an article publish in Financial Times, Cale Tilford (2018), notice that a quarter of the world's population are millennials. Also known as Generation Y, Millennials are the clients of the future, because "... Millennials access digital media on daily basis and have the ability to communicate with and purchase from suppliers anywhere in the world." (Mangold \& Smith, 2012:141). In this reality, Augmented Reality can be used in tourism as a link between different exponents of these generation. Augmented reality has the potential to improve the tourist experience and help tourists to access relevant information, thus improving their knowledge regarding their touristic 
destination, while increasing levels of user's entertainment throughout the process (Fritz et al., 2005).

This essay describes the field of AR, including its definition, its development history, its benefits. To give an idea of the state of the art, some recent applications of AR technology are also discussed as well, both from tourism companies and tourists point of view.

\section{Literature review}

\subsection{AR Definitions}

Augmented reality (AR) is this technology to create a "next generation, reality-based interface" (Jacob, 2006).

On the reality-virtuality continuum by Milgram and Kishino (1994) (Fig. 1), AR is one part of the general area of mixed reality.

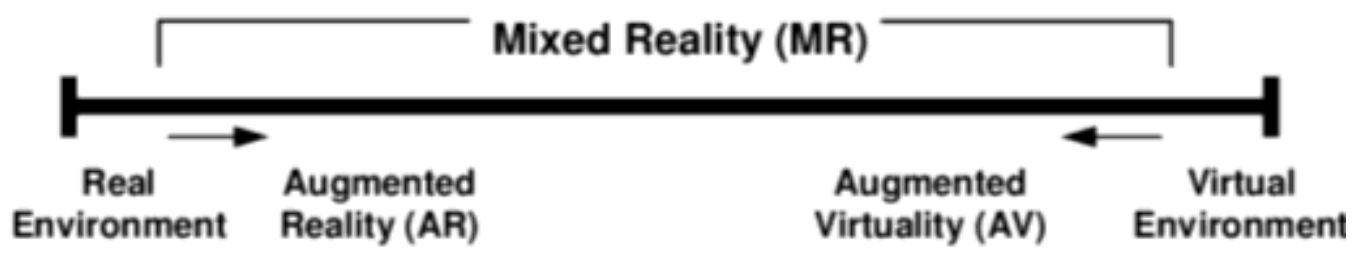

Figure 1 - Reality-virtuality continuum, adapted from Azuma et al. (2001).

Both virtual environments (or virtual reality) and augmented virtuality, in which real objects are added to virtual ones, replace the surrounding environment by a virtual one. In contrast, AR takes place in the real world. Following the definitions in (Azuma, 1997; Azuma et al., 2001), an AR system:

- combines real and virtual objects in a real environment;

- registers (aligns) real and virtual objects with each other; and

- runs interactively, in three dimensions, and in real time.

In Krevelen and Poelman opinion, three aspects of this definition are important to mention. Firstly, it is not restricted to particular display technologies such as a head-mounted display (HMD). Nor is the definition limited to the sense of sight, as AR can and potentially will apply to all senses, including hearing, touch, and smell. Finally, removing real objects by overlaying virtual ones, approaches known as mediated or diminished reality, is also considered AR (Krevelen \&Poelman, 2007).

\subsection{Brief history of $A R$}

Augmented Reality got exponentially more popular in recent years but it's been around for longer than you might think.

In table 1 Brief History of AR, we summarize the major milestones in Augmented Reality. Augmented Reality has largely evolved over the last decade to Mobile Augmented Reality. The first instance of AR can certainly be associated with the development of wearable AR, in a sense of experiencing AR during locomotion (mobile as a motion). With the transformation and miniaturization of physical devices and displays, the concept of AR evolved. 


\begin{tabular}{|c|c|}
\hline Year & Steps in developing Augmented Reality Technology \\
\hline 1901 & $\begin{array}{l}\text { Lyman Frank Baum, the author of "The Wonderful Wizard of Oz", published } \\
\text { an illustrated novel called "The Master Key" where he imagines a kind of } \\
\text { augmented reality. He describes a "character maker" - a set of electronic } \\
\text { spectacles, that when you view someone through them, the spectacles would } \\
\text { show a letter on that person's forehead regarding their character. The } \\
\text { protagonist even jokes that this technology is "a century ahead of the times". }\end{array}$ \\
\hline 1968 & $\begin{array}{l}\text { The computer scientist Ivan Sutherland developed the first ever VR and AR } \\
\text { head-mounted display (HMD) system, called "The Sword of Damocles". It used } \\
\text { computer-generated graphics to show users simple wireframe drawings. }\end{array}$ \\
\hline 1974 & $\begin{array}{l}\text { Computer artist Myron Krueger established an "artificial reality" laboratory } \\
\text { called "Videoplace". It combined projectors, video cameras, and special purpose } \\
\text { hardware that emitted onscreen silhouettes, surrounding the users in an } \\
\text { interactive environment. }\end{array}$ \\
\hline 1990 & $\begin{array}{l}\text { The term "augmented reality" is used for the first time. It was used by the } \\
\text { Boeing researcher Tom Caudell. His colleague David Mizell and he proposed } \\
\text { that workers configuring the airplane wiring wear HMDs that would project } \\
\text { airplane schematics onto reusable boards. }\end{array}$ \\
\hline 1992 & $\begin{array}{l}\text { Louis Rosenberg developed "Virtual Fixtures", one of the earliest functioning } \\
\text { AR systems, built for training pilots in the US Air Force. }\end{array}$ \\
\hline 1992 & $\begin{array}{l}\text { A team of people from the Columbia Univeristy built an HMD with trackers } \\
\text { attached called KARMA - Knowledge-based Augmented Reality for } \\
\text { Maintenance Assistance. }\end{array}$ \\
\hline 1994 & $\begin{array}{l}\text { Julie Marin created the first AR theater production "Dancing in Cyberspace" } \\
\text { with acrobats dancing around virtual objects on a physical stage. }\end{array}$ \\
\hline 1999 & $\begin{array}{l}\text { NASA X-38 spacecraft was flown using a Hybrid Synthetic Vision system that } \\
\text { used augmented reality to overlay map data to provide enhanced visual } \\
\text { navigation during flight tests. }\end{array}$ \\
\hline 2000 & $\begin{array}{l}\text { Hirozaku Kato created the ARToolkit - an open-source software library that } \\
\text { combined virtual graphics with real life using video tracking to overlap computer } \\
\text { graphics on a video camera }\end{array}$ \\
\hline 2009 & ARToolkit brought AR to web browsers. \\
\hline 2009 & $\begin{array}{l}\text { Esquire Magazine prompted their readers to scan the cover to make Robert } \\
\text { Downey Jr. come alive on the page. This was the first time a print media used } \\
\text { AR. }\end{array}$ \\
\hline 2013 & $\begin{array}{l}\text { Google started working on the "Glass" and just a few months after Google } \\
\text { opened their "Glass" to developers, car manufacturers Audi and Volkswagen } \\
\text { showcased their own AR mobile applications relating to instruction manuals and } \\
\text { remote assistance services. And even though the "Glass" wasn't a successful } \\
\text { project, it was a very important step into the future. Wearable AR technology is } \\
\text { surely a part of our future. }\end{array}$ \\
\hline 2014 & $\begin{array}{l}\text { In February, Google announces Project Tango, which is an Android smartphone } \\
\text { equipped with a full Kinect-like 3D sensor and hands out a few hundred units to } \\
\text { developers and companies. }\end{array}$ \\
\hline 2015 & $\begin{array}{l}\text { In January, Microsoft announces the Hololens, a headset to fuse AR and VR to } \\
\text { be made available later in } 2015 \text {. The device is a complete computer with a see- } \\
\text { through display and several sensors. }\end{array}$ \\
\hline
\end{tabular}

Source: https:// www.igreet.co/brief-bistory-of-angmented-reality/ and Arth et al. 2015 


\section{AR in tourism}

AR technology is currently used in several fields, such as medicine, education and simulated training among others (Yu et al, 2010). It is also used within the tourism sector. AR in tourism has a great potential to enhance travellers' experiences. As Garcia-Crespo et al. (2009) argue, the tourism industry is currently in need of technology-based integrated value- added services, which are highly dynamic and offer interactivity and entertainment. Augmented Reality has proven so far to be a technology that can provide tourists, and citizens of course, with much more personalized content and services tailored to their needs (Kounavis et al., 2012).

\subsection{The benefits of $A R$}

Over recent times, augmented reality has become increasingly popular within the travel industry. This is primarily because it enables hotels and other businesses operating in this field to enhance the physical environments, they are trying to encourage customers to visit, including local sights and hotel rooms.

On the one hand, several examples have shown that AR can aid tourist organizations and professionals towards reaching a wider audience by serving as the delivery technology of appealing multimedia content and mobile applications, fine-tuned to various knowledge levels. On the other hand, AR information systems can help tourists in accessing valuable information and improving their knowledge regarding a touristic attraction or a destination, while enhancing the tourist experience and offering increased levels of entertainment throughout the process (Fritz et al., 2005).

Unlike other purchases, travel tends to be heavily researched, as customers require lots of information before they arrive. In addition, this need for information does not stop when the customer arrives. Augmented reality can serve to ensure much of this information is available to them, 24/7, at times it is most relevant.

Furthermore, one of the keys to AR adoption within the travel industry has been the general change in consumer lifestyles over the past decade. Modern customers are already in the habit of using their smartphone a lot, even when they travel, so the step towards using augmented reality apps on those phones is not a big one.

\subsection{Smart AR aplications change the face of tourism}

Successful marketing requires adaptation and dynamism. In today economy providing a tangible opportunity to differentiate the organization, hotel or resort from the competition, is the very essence of hospitality marketing. Several applications have been developed based on the available frameworks and toolkits. While many begun as pilot applications or research projects, some of them are today commercially available. Most importantly, however, the examples are extremely varied. New AR mobile apps provide useful information, navigation, guides, and translations.

\section{Conclusions}

As we continue to develop and become more intelligent consumers, it is clear that "experiences" are the key to creating sustainable competitive advantage. Creating "memorable experiences" in tourism is the key to future.

Traveling is always new experiences. With AR tools this is truer than ever, and what's more, augmented reality in tourism comes very handy for:

- hotel tours, booking

- accessible travel information

- no language barriers

- advanced navigation

And as professor Dimitrios Buhalis from Bournemouth University, UK said somewhat metaphorically, but very precisely (Buhalis, 2016): augmented reality is where the real future of the hospitality business lies. 
Acknowledgement: This research was supported by The Project Future Web (PN-III-P1-1.2PCCDI2017-0800). We thank our colleagues from Academy of Economic Studies and Dunarea de Jos University who provided insight and expertise that greatly assisted the research.

\section{References}

1. Ariso, J.M (2017). Augmented Reality, Berlin Studies in Knowledge Research, Volume 11, pp.3

2. Bubalis, D. (2016). How Augmented Reality is Redefining 21st-Century Hotels, Valtech_Insight, bttps:// wnw.valtech.com/insights/how-augmented-reality-is-redefining-21st-century-hotels/, visited on 17 May 2019.

3. David, P. A., \& Foray, D. (2002). An introduction to the economy of the knowledge society. International social science journal, 54(171), 9-23.

4. UNESCO (2005). Towards Knowledge Societies. http://unesdoc.unesco.org/images/0014/ 001418/141843e.pdf., visited on 14 May 2019.

5. Tilford, $C$ (2018). Financial Times, https://mmw.ft.com/content/f81ac17a-68ae-11e8-b6eb4 acfcfb08c11, visited on 17 May 2019

6. Mangold, W., \& Smith, K. (2012). Selling to Millennials with online reviews. Business Horizons, 55(2), 141-153. bttp:/ / dx.doi.org/10.1016/j.bushor.2011.11.001

7. Fritz, F.; Susperregui, A. and Linaza, M.T. (2005), Enhancing cultural tourism experiences with augmented reality technologies. 6th International Symposium on Virtual Reality, Archaeology and Cultural Heritage ( $V A S T)$

8. Jacob, R. J. (2006, April). What is the next generation of buman-computer interaction?. In Conference on Human Factors in Computing Systems: CHI'O6 extended abstracts on Human factors in computing systems (Vol. 22, No. 27, pp. 1707-1710).

9. Azuma, R., Baillot, Y., Behringer, R., Feiner, S., Julier, S., \& MacIntyre, B. (2001). Recent advances in augmented reality. IEEE computer graphics and applications, 21(6), $34-47$.

10. Azuma, R. T. (1997). A survey of augmented reality. Presence: Teleoperators \& Virtual Environments, 6(4), 355-385.

11. Milgram, P., \& Kishino, F. (1994). A taxonomy of mixed reality visual displays. IEICE TRANS ACTIONS on Information and Systems, 77(12), 1321-1329.

12. Van Krevelen, D., \& Poelman, R. (2007). Augmented reality: Technologies, applications, and limitations. Vrije Univ. Amsterdam, Dep. Comput. Sci.

13. IgreetStories (2018), Brief History of Augmented Reality https:/ / wnw.igreet.co/brief-bistory-of-angmentedreality/, visited on 17 May 2019

14. Arth, C., Grasset, R., Gruber, L., Langlot:, T., Mulloni, A., \& Wagner, D. (2015). The history of mobile angmented reality. arXiv preprint arXiv:1505.01319.

15. Yu D, Jin JS, Luo S, Lai W, Huang Q. (2010) A Useful Visualization Technique: A Literature Review for Augmented Reality and its Application, limitation and future direction. In: Huang ML, Nguyen QV, Zhang K, editors. Visual Information Communication: Springer US. pp. 311-37

16. Fritz F, Susperregui A, Linaza M. (2005) Enhancing cultural tourism experiences with augmented reality technologies. Paper presented at the 6th International Symposium on Virtual Reality, Archaeology and Cultural Heritage (V AST). Pisa, Italy

17. García-Crespo A, Chamizo J, Rivera I, Mencke M, Colomo-Palacios R, Gómez-Berbís JM. (2009) SPETA: Social pervasive e-Tourism advisor. Telematics and Informatics. 26: 306-15

18. Kounavis, C. D., Kasimati, A. E., \& Zamani, E. D. (2012). Enhancing the tourism experience through mobile augmented reality: Challenges and prospects. International Journal of Engineering Business Management, 4, 10.

19.https: / thinkmobiles.com/blog/angmented-reality-tourism/

20.https: / / wnw.revfine.com/ augmented-reality-travel-industry/

21. https:/ / thinkdigital.travel/ wp-content/ uploads/2013/04/10-AR-Best-Practices-in-Tourism.pdf. 